\title{
Applied Craniometry for Dog Skulls from the Pecica- "Șanțul Mare" (Arad County) and Sântion (Bihor County) Bronze Age Sites
}

\author{
Xenia POP, Alexandru GUDEA*, Aurel DAMIAN \\ Faculty of Veterinary Medicine, University of Agricultural Sciences and Veterinary Medicine, \\ Calea Mănăștur 3-5,400372, Cluj-Napoca, România \\ *corresponding author: alexandru.gudea@usamvcluj.ro \\ Bulletin UASVM Veterinary Medicine 75(2)/2018 \\ Print ISSN 1843-5270; Electronic ISSN 1843-5378 \\ doi:10.15835/buasvmcn-vm:2018.0005
}

\begin{abstract}
:
The present study deals with the craniometrical investigation carried on 4 dog crania originating from archaeological diggings dated from Bronze Age in Pecica-,„Șanțul Mare”(Arad County) and Sântion (Bihor County). In order to determine the typology of the crania, the classical osteometrical methods were applied, with several cranian point measurements. The cranial, the cranian and facial indices helped us in the morphometrical characterisation of the canid skulls studied. Our results show the prevalence of the mesocephalic individuals in Pecica-,,Șanțul Mare” and Sântion.
\end{abstract}

Keywords: archaeozoology, bronze age, craniometry, dog, skulls

\section{Introduction}

Craniometry represents the sum of the measurements taken at the level of the skull. It has a series of applications in zoology as well as in archeozoology, being based on the same principles as in anthropology. The shape of the cranium is an important criterion for the establishment of the dog breed standards and the cranian indexes are also a useful tool for the identification and/ or definition of morphological types (Alpak et al.,, 2004).

Dog was one of the first domesticated animal (Bökönyi 1974), being considered throughout history a good companion, used for hunting or guarding of the domestic space (Gligor 2011). This is the reason that led to the systematic selection of different morphotypes that finally ended in a clear diversification of the species (Onar et al., 2012).

We present new craniometrical investigations on 4 Canis familiaris individuals originating from 2 Bronze Age archaeological sites.
One of the studied skulls originate from the archaeological diggings from the Sântion tell (Bihor County) ${ }^{1}$. The cranium was discovered in the complex no. 27, in the layer of the floors associated with other household waste, with a basal exposure (see Fig.1.a, b), while other skeletal parts were missing (Pop, in press). Based on the degree of fusion, dental attrition and eruption, the individual was evaluated as being an adult (Schmid 1972, Barone 1976, Udrescu et al., 1999).

The other 3 skulls (Fig.2) originate from the collection of the Arad Museal Complex and were aquired during the first archaeological campaigns conducted by Dömötör in 1898, 1900, 1901 and 1902 (Dömötör 1898, Dömötör 1900, Dömötör 1901, Dömötör 1902) in Pecican „Șanțul Mare" (Arad County). The crania belong to adult individuals and were dated to the Middle Bronze Age, Mureș/Maros Culture.

1 The archaeological investigation was carried by Dr. Fl. Gogâltan (Institute of Archaeology, Romanian Academy, Cluj) in 2015. 


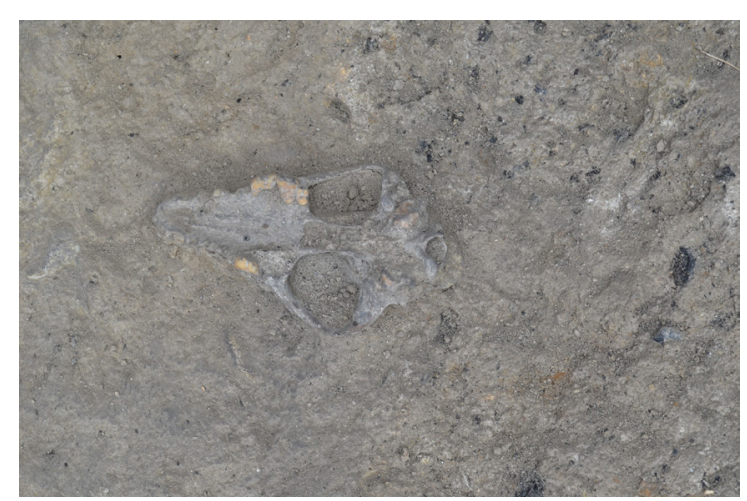

a)

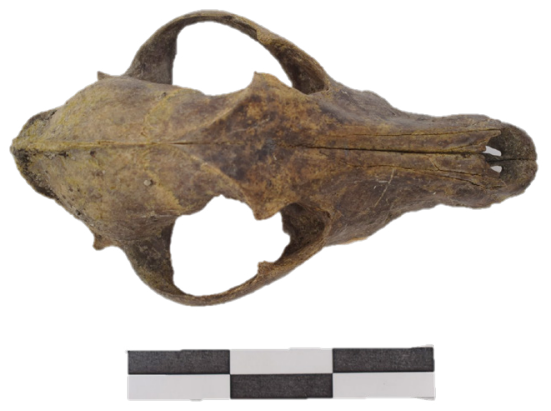

b)

Figure 1. Sântion dog skull: a) basal view; b) dorsal view
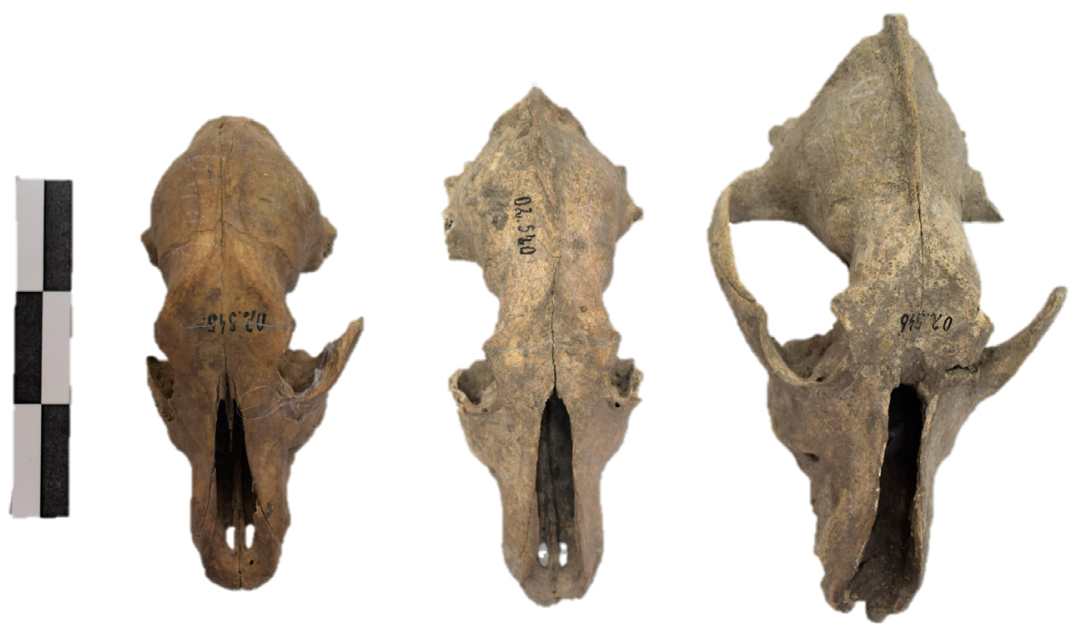

Figure 2. Crania from Pecica-"Șanțul Mare"

Considering the metrical data recorded on some dog skulls from archaeological excavations and using the craniometry-speciality literature, the present study presents some of the known Canis cranial typologies described for prehistoric specimens.

\section{Materials and methods}

The craniometrical investigation was applied on the 4 crania from Middle Bronze Age, originating from sites of Pecica "Șanțul Mare” and Sântion. For the material originating from "Şanțul Mare" we have the following original identifiers: specimen A (nr inv.02.540), specimen B (nr.inv.02.545) and specimen C (nr.inv.02.546).

The comparative measurements were done for each cranium in the Comparative Anatomy Laboratory on the Faculty of Veterinary Medicine Cluj-Napoca. The methods used were in accordance to the von den Driesch (1976), Evans and Christensen (1993), Alpak et al.,(2004), Onar et al.,(2001) methodology.

The osteometrical landmarks used were the following:

- Maximum zygomatic width (Zy - Zy);

- Maximum width of neurocranium (Eu - Eu);

- Skull length (Akr - Phr);

- Cranial length (Akr - N);

- Viscerocranium length (N - Phr).

The formulas for the indices were:

- Skull index= maximum zygomatic width*100/ skull length

- Cranial index = maximum width of neurocranium*100/cranial length

- Facial index $=$ maximum zygomatic width*100/ viscerocranium length 
Table 1. Skull measurements (mm) on Pecica-,,Șanțul Mare” and Sântion Bronze Age skulls

\begin{tabular}{ccccc}
\hline & \multicolumn{3}{c}{ Pecica - „Şanțul Mare” } & Sântion \\
\cline { 2 - 5 } Craniometric data (mm) & $\begin{array}{c}\text { Specimen A } \\
\text { Nr.inv. 02.540 }\end{array}$ & $\begin{array}{c}\text { Specimen B } \\
\text { Nr.inv.02.545 }\end{array}$ & $\begin{array}{c}\text { Specimen C } \\
\text { Nr. inv.02.546 }\end{array}$ & Cranium \\
\hline $\begin{array}{c}\text { Maximum zygomatic width } \\
\text { Zy - Zy) }\end{array}$ & - & $\sim 104$ & $\sim 123$ & 106 \\
\hline $\begin{array}{c}\text { Maximum width of } \\
\text { neurocranium (Eu - EU) }\end{array}$ & 48 & 47 & 47 & 49 \\
\hline Skull length (Akr - Phr) & 175 & 155 & 207 & 189 \\
\hline Cranial length (Akr - N) & 98 & 86 & 112 & 105 \\
\hline $\begin{array}{c}\text { Viscerocranium length } \\
\text { (N - Phr) }\end{array}$ & 86 & 76 & 102 & 94 \\
\hline
\end{tabular}

Table 2. Calculated indices of Pecica-,Șanțul Mare” and Sântion skulls

\begin{tabular}{ccccc}
\hline \multirow{2}{*}{ Indices } & \multicolumn{3}{c}{ Pecica -,„Şanțul Mare” } & Sântion \\
\cline { 2 - 5 } & Specimen A & Specimen B & Specimen C & \multirow{2}{*}{ Cranium } \\
\hline Nr.inv. 02.540 & Nr.inv.02.545 & Nr. inv.02.546 & \\
\hline Skull index & - & 67,10 & 59,42 & 56,08 \\
\hline Cranial index & 48,98 & 54,64 & 41,96 & 99,04 \\
\hline Facial index & - & 136,84 & 120,59 & 112,76 \\
\hline
\end{tabular}

Table 3. Calculated indices of Jászdózsa-"Kápolna halom" and Carei-"Bobald" skulls

\begin{tabular}{cccc}
\hline \multirow{2}{*}{ Indices } & \multicolumn{2}{c}{ Jászdózsa "Kápolna halom” } & Carei „Bobald” \\
\cline { 2 - 4 } & Cranium 1 & Cranium 2 & Cranium \\
\hline Skull index & - & - & 48,71 \\
\hline Cranial index & - & - & - \\
\hline Facial index & 77,5 & 71,59 & 95 \\
\hline
\end{tabular}

\section{Results and discussion}

The series of measurements taken can be found in Tables 1 and 2 . Some of the measurements were impossible to record due to fragmentation of the specimens, hence the incomplete indices.

The evaluation of the metrical data shows higher values for specimen $C$ Pecica individual and Sântion individual; for specimens $\mathrm{A}$ and $\mathrm{B}$ from Pecica, the metrical data are similar and seem lower than the ones recorded in case of the previous specimens.

For skulls A, B and C, originating from Pecica "STanțul Mare" site, the values the skull index indicated the values close to the brachycephalic type (specimen B) and much closer to mesocephalic values for specimen $C$. The calculated values for the cranial index for specimens $\mathrm{C}$ and A suggest the proximity to the lower limit for the mesocephalic skulls, while for the 3-rd specimen (specimen B), we are in the middle of the range. The facial index was calculated only for specimens B and C, showing values similar for mesocephalic individuals, with a slight tendency towards higher values specific to brachycephalic types.

For the Sântion individual the values for the skull and facial indexes show values in the mesocephalic types, while the cranial index has a slight decreasing tendency (dolicocephalic types).

The calculation of the indexes allowed the framing of the specimens into the 3 craniological types: brachycephalic, mesocephalic and dolicocephalic. Generally speaking, our results show a relative prevalence of a mesocephalic type. 
We can compare our data to previously published ones: from Carei-„Bobald” (El Susi 2002) and from Jászdózsa „Kápolna halom” (Hungary) (Vörös 1996) (Table 3).

The skull from Carei „Bobald” values are close to the mesocephalic type, with a slight tendency towards the dolicocephalic type (for the cranian index) and slightly orientated towards the dolicocephalic type (when the facial index is considered). For speciemens 1 and 2 originating from Jászdózsa „Kápolna halom”, the values of facial indexes descreases significantly towards the lower value for dolicocephalic type.

The obtained results show a mesocephalic typology for the Pecica „Șanțul Mare”, Sântion and Carei „Bobald” specimens. For Jászdózsa „Kápolna halom" speciemens, the obtained values show a dolicocephalic typology.

\section{Conclusion}

The present study shows the predominance of the mesocephalic individuals in the studied sites. An exceptional comparative situation is represented by the 2 Jászdózsa-,,Kápolna halom” skulls where figures show the existence of dolicocephalic individuals.

Acknowledgments. This research did not receive any specific grant from funding agencies in the public, commercial, or not-for-profit sectors.

\section{References}

1. Alpak H, Mutuș R., Onar V (2004). Correlation of the skull and long bone measurements of the dog, in Annals of Anatomy 186:323-330.

2. Barone R (1976). Anatomie compare des mammiferes domestiques, T1. Ed. Vigot Freves, Paris.

3. Bökönyi S (1974). The History of Domestic Mammals in Central and Eastern Europe. Akadémiai Kiadó, Budapest.

4. Dömötör L (1898). Jelentés a pécskai - iletve német peregi ásatásokrol. (manuscript)
5. Dömötör L (1900). Az aradi Kölcsey-Egyesület választmányához intézett jelentése Dömötör Lászlónak a m.- pécskai N. - Sánczon 1900 évi aug.hoban végzett ásatásárol. (manuscris).

6. Dömötör L (1901). Dömötör László áll. Főreálisk tanár jelentése a m. pécscai őstelepen az 1901 év nyarán végyett ásatásról, in Az Aradi Kölcsey-Egyesület 1901.Évi Működése.Arad.

7. Dömötör L (1902). Dömötör László áll. Főreálisk tanár jelentése az 1902 évi nyarán a m. pécscai őstelepen folytatott ásatásról.(manuscript).

8. El Susi Georgeta (2002) Cercetări arheozoologice în așezarea de epoca bronzului de la Carei-„,Bobald” (Județul Satu-Mare) in Thraco-Dacica, tome XXIII, 1-2:243-265.

9. Evans HE, Christensen GC (1993). The skeletal system (skull), in Miller's Anatomy of the Dog, 3rd edition, chapter 1, Philadelphia:W.B.Saunders Co, p. 6-49.

10. Gligor M (2011). Relația om-câine în preistorie: Resturi scheletice umane și de canide. Practici mortuare, dovezi arheologice și posibile semnificații [HumanDog Relationship: Human and Canids Bone Remains. Mortuary Practices, Archaeological Evidence and Possible Interpretations], in Analele Banatului. Arheologie-Istorie, XIX, 2011, p. 51-66.

11. Onar V, Çakirlar C,Janeczek M, Kiziltan Z (2012). Skull Typology of Byzantine Dogs from the Theodosius Harbour at Yenikapi, Istanbul. Anatomia Histologia Embryologia. Journal of Veterinary Medicine, 41:341-354.

12. Pop Xenia, (in press).Un craniu de câine provenit din situl de epoca bronzului de la Sântion In Fl.Gogâltan, Cristina Cordoș (Eds), Archaeological investigations in the Bronze Age tell settlements from Sântion and Toboliu.

13. Udescu M, Bejenaru Luminița, Hrișcu Carmen (1999). Introducere în arheozoologie. Editura Corson. Iași.

14. Schmid Elisabeth (1972). Atlas of Animal Bones. For Prehistorians, Archaeologist and Quaternary Geologist. Elsevier Publishing Company. Amsterdam.

15. Von den Driesch Elisabeth (1976). A Guide to the Measurement of Animal Bones from Archaelogical Sites, in Peabody Museaum Bulletin 1. Hovard University.

16. Vörös I (1996). Dog as building offering from the Bronye Age tell at Jászdózsa. Folia Archaeologica XLV:69-90. 